\title{
Uptake of glycine betaine and its analogues by bacteroids of Rhizobium meliloti
}

\author{
F. FougÈRE and D. LE RUDULIER*
}

Laboratoire de Biologie végétale et Microbiologie, URA CNRS 79, Faculté des Sciences et des Techniques, Université de Nice, Parc Valrose, 06034 Nice Cédex, France

(Received 28 June 1989; revised 25 August 1989; accepted 19 September 1989)

\begin{abstract}
Bacteroids isolated from alfalfa nodules induced by Rhizobium meliloti 102F34 transported glycine betaine at a constant rate for up to $30 \mathrm{~min}$. Addition of sodium salts greatly increased the uptake activity, whereas other salts or non-electrolytes had less effect. The apparent $K_{\mathrm{m}}$ for glycine betaine uptake was 8.3 $\mu \mathrm{M}$ and $V$ was about $0.84 \mathrm{nmol} \mathrm{min}^{-1}$ (mg protein) ${ }^{-1}$ in the presence of $200 \mathrm{mM}-\mathrm{NaCl}$ which gave maximum stimulation of the transport. Supplementing bacteroid suspensions with various energy-yielding substrates, or ATP, did not increase glycine betaine uptake rates. The uncoupler carbonyl cyanide $m$-chlorophenylhydrazone (CCCP), and the respiratory inhibitor potassium cyanide strongly inhibited glycine betaine uptake, but arsenate was totally inactive. Glycine betaine transport showed considerable structural specificity: choline, proline betaine, $\gamma$-butyrobetaine and trigonelline did not competitively inhibit the system, although choline and proline betaine were transported by bacteroids. Both a high-affinity activity and a low-affinity activity were found for choline uptake. These osmoprotective compounds might have a significant role in the maintenance of nitrogenase activity in bacteroids subjected to salt stress.
\end{abstract}

\section{Introduction}

Recent work has shown that Rhizobium meliloti is able to overcome growth inhibition caused by osmotic stress by uptake of osmoprotectants such as glycine betaine or proline betaine from the medium (Bernard et al., 1986; Gloux \& Le Rudulier, 1989). Both compounds are accumulated in osmotically stressed cells. In $R$. meliloti, choline also functions as an osmoprotectant, but only because it is oxidized to glycine betaine (Le Rudulier $e t$ al., 1984a; Smith et al., 1988). The transport of this compound is catalysed by three kinetically distinct transport systems: a high- and a low-affinity activity constitutively expressed, and a second high-affinity activity induced by choline (Pocard et al., 1989).

Glycine betaine and proline betaine can partially restore the symbiotic nitrogen fixation ability of young nodulated alfalfa (Medicago sativa) subjected to salt stress (Pocard et al., 1984). This suggests an important role for betaines as osmoprotective molecules in the nodules. Interestingly, $\boldsymbol{M}$. sativa synthesizes proline betaine (Sethi \& Carew, 1984) and we have recently

\footnotetext{
Abbreviations: CCCP, carbonyl cyanide $m$-chlorophenylhydrazone;
} $\mathrm{MDH}$, malate dehydrogenase. shown that proline betaine is also present in salt-stressed nodules of this plant (K. Gloux \& D. Le Rudulier, unpublished). In addition, evidence has been obtained that phosphatidylcholine acts as a precursor of glycine betaine in other plants (Hitz et al., 1981; Giddings \& Hanson, 1982).

Despite the attention given to transport systems in bacteroids, to date there are no published studies characterizing betaines or choline transport activities in these symbiotic cells. This report describes glycine betaine uptake by bacteroids of $R$. meliloti under osmotic stress and in the presence of different energy-yielding substrates. Results of experiments investigating proline betaine and choline transport are also presented.

\section{Methods}

Organism and culture conditions. Rhizobium meliloti 102F34 was kindly supplied by R. C. Valentine (University of California, Davis, CA, USA). It was maintained on solid mannitol/salts/yeast extract (MSY) medium of O'Gara \& Shanmugan (1976). Batch cultures were grown aerobically at $30^{\circ} \mathrm{C}$ in MSY for $24 \mathrm{~h}$ with shaking at 150 r.p.m. Cell growth was measured as optical density at $420 \mathrm{~nm}$. The cells were harvested at $\mathrm{OD}_{420}=1.5$ by centrifugation $(7000 \mathrm{~g}$ for $10 \mathrm{~min})$,

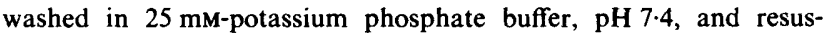
pended at a cell density of $2 \times 10^{9}$ cells $\mathrm{ml}^{-1}$. 
Nodule production. Plants were obtained by clonal propagation of shoot cuttings from a single plant of Medicago sativa L. (cv. Europe). The cuttings were maintained on water for 1 week and then on the minimal salts medium of Sirois \& Peterson (1982) with $5 \mathrm{~mm}-\mathrm{KNO}_{3}$ for 2 weeks. At this stage, the roots were rinsed with distilled water and the plants were transferred to an aeroponic device (plastic tank, 250 litres) containing 10 litres of nitrogen-free salts solution (Sirois \& Peterson, 1982) and a mist generator (Defensor 505). Shoots and roots were separated by a plastic cover-plate with $3 \mathrm{~cm}$ diameter holes fitted with notched rubber stoppers. Each stopper supported one plant through a $1.0 \mathrm{~cm}$ diameter hole containing one Eppendorf microtube filled with agar. The plants were immediately inoculated by adding a washed suspension of bacteria ( $5 \mathrm{ml}$ for each plant) into the plastic tank. Two weeks after inoculation the plastic cover supporting the plants was transferred to a tank (65 litres) containing 20 litres of Sirois and Peterson medium. The bottom of this tank was fitted with an aeration tube, and air was provided to the root system at 3.7 litres $\mathrm{min}^{-1}$. The roots were $30 \%$ immersed in the medium. Four-week-old nodules were harvested and used immediately for bacteroid preparation. Nodules obtained from plants grown through this two-step procedure showed a two to three times greater acetylene reduction activity than nodules collected from plants maintained in the aeroponic device for 4 weeks. During the whole process, plants were grown in a greenhouse with $16 \mathrm{~h}$ of light each day; the nutrient solution was renewed weekly. Natural light was supplemented with $400 \mathrm{~W}$ Phytoclaude lamps. Day and night temperatures were approximately $27^{\circ} \mathrm{C}$ and $20^{\circ} \mathrm{C}$, respectively.

Bacteroid isolation. Nodules (3-4 g fresh wt) were surface-sterilized with calcium hypochlorite $(0.5 \%, \mathrm{pH} 7.0)$ for $5 \mathrm{~min}$ and thoroughly rinsed with sterile distilled water. The nodules were then crushed using a mortar and pestle in the mixture described by Bergersen \& Turner (1970). After filtration, the homogenate was centrifuged at $270 \mathrm{~g}$ for $5 \mathrm{~min}$ to remove insoluble polyvinylpyrrolidone and plant cell debris. Bacteroids were separated by a second centrifugation $(6800 \mathrm{~g}, 10 \mathrm{~min})$ and washed twice with $50 \mathrm{~mm}$-potassium phosphate buffer ( $\mathrm{pH} \mathrm{7.4)}$ containing sucrose $(300 \mathrm{mM})$ and magnesium sulphate $(2 \mathrm{mM})$ as described by Rigaud et al. (1973). They were finally resuspended in 25 mM-potassium phosphate buffer ( $\mathrm{pH} \mathrm{7.4)}$ to a final concentration of $40 \mathrm{mg}$ dry $\mathrm{wt}^{-1} \mathrm{l}^{-1}$.

Determination of oxygen consumption. Bacteroid suspensions $(2 \mathrm{ml})$ containing $0.25 \mathrm{mg}$ protein were incubated in the chamber of a Hansatech oxygen electrode at $25^{\circ} \mathrm{C}$ with $10 \mathrm{~mm}$-succinate as energyyielding substrate. Glycine betaine and $\mathrm{NaCl}$ were added at $10 \mathrm{~mm}$ and 50-600 mM, respectively. Results are expressed as nmol $\mathrm{O}_{2}$ consumed $\min ^{-1}$ (mg protein) $)^{-1}$.

Uptake experiments. Transport activities of bacteroids were determined immediately upon completion of the bacteroid isolation procedure. The method used was that described for transport assays in free-living cells (Perroud \& Le Rudulier, 1985). Individual uptake experiments (final volume $0.5 \mathrm{ml}$ ) were done aerobically at $25^{\circ} \mathrm{C}$, at least in duplicate, and each experiment was repeated with two or three independent bacteroid preparations. Unless otherwise indicated, the substrate concentration in the assay mixture $(25 \mathrm{~mm}$-potassium phosphate buffer, $\mathrm{pH} 7.4)$ was $50 \mu \mathrm{M}$ for $\left[{ }^{14} \mathrm{C}\right]$ glycine betaine and $\left[{ }^{14} \mathrm{C}\right]$ choline and $10 \mu \mathrm{M}$ for $\left[{ }^{14} \mathrm{C}\right]$ proline betaine. Salts, osmotic agents, energy-yielding substrates or inhibitors were added to the bacteroid suspension $5 \mathrm{~min}$ before addition of ${ }^{14} \mathrm{C}$-labelled substrate. In competition experiments, bacteroids were added to a mixture of labelled substrate and unlabelled analogues. The reaction was stopped by rapid filtration through a cellulose nitrate filter $(0.45 \mu \mathrm{m}$ pore size), which was rinsed twice with $3 \mathrm{ml}$ of the corresponding assay medium. Radioactivity accumulated by the bacteroids was measured after $30 \mathrm{~min}$ incubation. During this period uptake was linear at the concentrations used. The filters were solubilized in scintillation vials containing $2.5 \mathrm{ml}$ of ACS scintillant, (Amersham) and radioactivity was determined about $24 \mathrm{~h}$ later in a liquid-scintillation counter.

Cellular volumes. Intracellular aqueous volumes were determined by the $\left[{ }^{3} \mathrm{H}\right]$ water $/\left[{ }^{14} \mathrm{C}\right]$ dextran technique of Stock et al. (1977). Values were $6.9 \pm 0.7$ and $5.2 \pm 0.3 \mu \mathrm{l}(\mathrm{mg} \text { protein })^{-1}$ for bacteroids resuspended in $25 \mathrm{~mm}$-potassium phosphate buffer and the same buffer with $0.2 \mathrm{M}-\mathrm{NaCl}$ added, respectively.

Radioisotopes. [methyl- $\left.{ }^{14} \mathrm{C}\right] \mathrm{Choline}\left(2 \cdot 15 \mathrm{MBq}^{-1} \mathrm{~mol}^{-1}\right)$ and $[$ carboxy$\left.{ }^{14} \mathrm{C}\right]$ dextran $\left(18.5 \mathrm{MBq} \mathrm{g}^{-1}\right.$ ) were purchased from Amersham and New England Nuclear, respectively. $\left[{ }^{3} \mathrm{H}\right]$ Water $\left(370 \mathrm{MBq} \mathrm{ml}^{-1}\right)$ and $\mathrm{L}-[\mathrm{U}-$ ${ }^{14} \mathrm{C}$ ]proline $\left(9.62 \mathrm{MBq} \mu \mathrm{mol}^{-1}\right.$ ) were from CEA (France). [methyl$\left.{ }^{14} \mathrm{C}\right]$ Glycine betaine was prepared from $\left[\right.$ methyl $\left({ }^{14} \mathrm{C}\right]$ choline as described by Perroud \& Le Rudulier (1985). [ $\left.{ }^{14} \mathrm{C}\right]$ Proline betaine was synthesized from L-[U-14 C]proline by the method of Corti (1949) as modified by Ikutani (1968). Analyses of purity were done as previously described (Gloux \& Le Rudulier, 1989).

Protein determinations. Total protein was assayed by the Lowry method using BSA as the standard.

\section{Results and Discussion}

\section{Oxygen uptake by bacteroids: effects of $\mathrm{NaCl}$ and glycine betaine}

The preparations were shown to be free from mitrochondria by the method described by Salminen \& Streeter (1987). Malate dehydrogenase (MDH) activity of bacteroids that had been passed through a French pressure cell [16000 p.s.i. (about $110 \mathrm{MPa}$ )] was tested with two inhibitors of mitochondrial MDH activity (Waters et al., 1985). After $70 \mathrm{~min}$ pre-incubation with $1 \mathrm{~mm}$-iodoacetate or $1 \mathrm{mM}-\mathrm{PMSF}, \mathrm{MDH}$ rates of 2.21 and $2 \cdot 17 \mu \mathrm{mol} \mathrm{min}^{-1}$ (mg protein) $)^{-1}$ were observed, whereas the untreated preparation gave a rate of $2.12 \mu \mathrm{mol} \mathrm{min}^{-1}$ (mg protein $)^{-1}$. These rates were comparable to the rates reported for $\mathrm{MDH}$ from bacteroid forms of Bradyrhizobium japonicum (Salminen \& Streeter, 1987), indicating that our bacteroid preparations were free of mitochondria. This was confirmed by examination of the bacteroid preparations by electron microscopy. In addition, virtually no contamination by free-living bacteria could be detected.

It is well-known that supplementing bacteroid suspensions with organic acids stimulates respiratory activity. However, to our knowledge, only one report deals with bacteroids of $R$. meliloti (Bekki et al., 1987). We have verified that the low respiratory activity supported by endogenous reserves $\left[5 \mathrm{nmol} \mathrm{O}_{2} \min ^{-1}(\mathrm{mg} \text { protein })^{-1}\right]$ was greatly increased by succinate, maximal stimulation being observed with $10-20 \mathrm{mM}$ substrate $\left[65 \mathrm{nmol} \mathrm{O}_{2}\right.$ $\min ^{-1}(\mathrm{mg} \text { protein })^{-1}$. Addition of other carbon sources, including malate, glucose, fructose or sucrose, only slightly enhanced respiration activity $\left[\begin{array}{lll}7-9 & \mathrm{nmol} & \mathrm{O}_{2}\end{array}\right.$ $\min ^{-1}(\mathrm{mg} \text { protein })^{-1}$, whereas fumarate had no effect. All subsequent experiments on the effects of salt stress on 
respiration activity were done in the presence of $10 \mathrm{mM}$ succinate (Fig. 1). Addition of $50-100 \mathrm{~mm}-\mathrm{NaCl}$ inhibited $\mathrm{O}_{2}$ consumption by only $20 \%$ and $24 \%$, respectively; $370 \mathrm{~mm}-\mathrm{NaCl}$ was necessary to reach $50 \%$ inhibition. When a concentration as high as $600 \mathrm{~mm}-\mathrm{NaCl}$ was added, $\mathrm{O}_{2}$ consumption was still $34 \%$ of the initial rate. Similar effects of $\mathrm{NaCl}$ on bacteroid respiration have been observed with bacteroids isolated from nodules of $M$. sativa inoculated with $R$. meliloti strain 2011, and nodules of $M$. ciliaris inoculated with $R$. meliloti strain ABS 7 (Bekki et al., 1987). The results are also in agreement with previously unpublished results obtained with free-living cells of $R$. meliloti strain 102F34 in which $50 \%$ inhibition of $\mathrm{O}_{2}$ consumption was observed when $440 \mathrm{~mm}-\mathrm{NaCl}$ was added to the incubation medium. Addition of $10 \mathrm{~mm}$-glycine betaine to a succinate-free medium did not stimulate bacteroid respiration either in the absence or the presence of $400 \mathrm{~mm}-\mathrm{NaCl}$ (results not shown). This contrasts with the case of free-living cells of $R$. meliloti where, in low-salt medium, glycine betaine is used as an energy-yielding substrate (Bernard et al., 1986), and thus stimulates $\mathrm{O}_{2}$ consumption 2 -fold. One possible explanation for this lack of stimulation in bacteroids might be loss of glycine betaine uptake activity during the differentiation process. Therefore, bacteroids were assayed for their ability to take up $\left[\right.$ methyl $\left.-{ }^{14} \mathrm{C}\right]$ glycine betaine.

Glycine betaine uptake by bacteroid preparations: effects of salts and osmolarity

In $R$. meliloti $102 \mathrm{~F} 34$, the glycine betaine uptake system is constitutive and strongly stimulated by increased

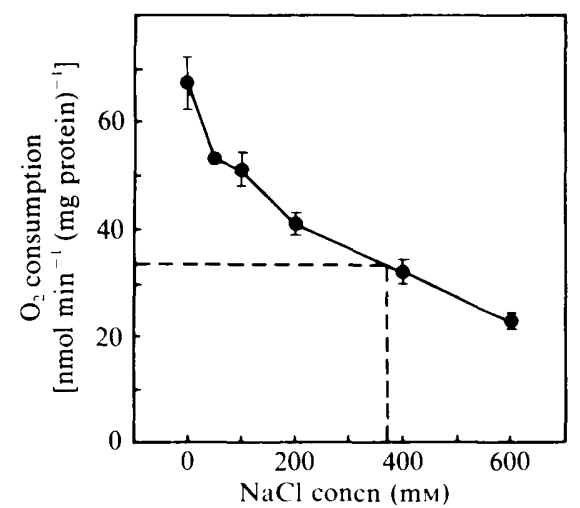

Fig. I. Influence of $\mathrm{NaCl}$ concentration on the rate of $\mathrm{O}_{2}$ consumption by bacteroids of $R$. meliloti. Measurements were made as described in Methods; incubation mixtures contained bacteroids $(0.25 \mathrm{mg}$ protein) and $10 \mathrm{~mm}$-succinate. Initial $\mathrm{O}_{2}$ concentration was assumed to be $253 \mu \mathrm{M}$ at $25^{\circ} \mathrm{C}$. - -, $\mathrm{NaCl}$ concentration giving $50 \%$ inhibition of respiration. Each point is the mean of at least three independent determinations; error bars indicate SD. osmolarity (Bernard et al., 1986). Similarly, bacteroids isolated from $M$. sativa nodules were able to transport $\left[{ }^{14} \mathrm{C}\right]$ glycine betaine at a very low rate in no-salt medium [6.5 $\mathrm{pmol} \mathrm{min}^{-1}$ (mg protein $\left.)^{-1}\right]$ and at a much higher rate in the presence of $\mathrm{NaCl}$ (Fig. 2). Maximal stimulation (120-fold) was observed with $200 \mathrm{~mm}-\mathrm{NaCl}$. Uptake was linear for at least 30 min under all conditions. After $30 \mathrm{~min}$, the intracellular concentration of glycine betaine in bacteroids treated with $200 \mathrm{~mm}-\mathrm{NaCl}$ was approximately $4.5 \mathrm{mM}$, which is 90 times higher than the concentration in the medium. In bacteroids not treated with $\mathrm{NaCl}$, the intracellular concentration was approximately $27 \mu \mathrm{M}$ compared to $50 \mu \mathrm{M}$ in the incubation mixture. These results suggest the existence of passive uptake in the absence of $\mathrm{NaCl}$, whereas active uptake occurs in the presence of $\mathrm{NaCl}$. The maximal velocity of glycine betaine uptake was nearly 15 -fold higher in freeliving cells of $R$. meliloti grown at $200 \mathrm{~mm}-\mathrm{NaCl}$ compared to bacteroids incubated under the same conditions. This agrees with the observation of San Francisco \& Jacobson (1985), who reported that uptake rates for succinate and malate were 20-25-fold higher in cultured cells compared to bacteroids of $B$. japonicum strain USDA 3278. Since we have recently characterized a periplasmic glycine betaine binding protein in $R$. meliloti grown in high-salt medium (unpublished result), one possible explanation for this large decrease in uptake

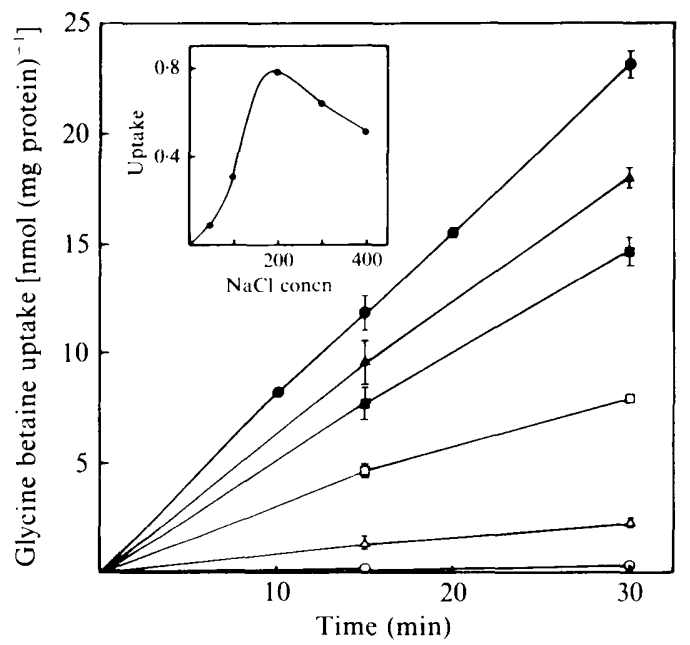

Fig. 2. Time-course of $\left[\right.$ methyl $\left.{ }^{-14} \mathrm{C}\right] \mathrm{glycine}$ betaine uptake by bacteroids of $R$. meliloti. Incubation mixtures $(0.5 \mathrm{ml})$ contained $50 \mu \mathrm{M}-$ [methyl ${ }^{-1+} \mathrm{C}$ ]glycine betaine and bacteroids $(0.1 \mathrm{mg}$ protein) in $25 \mathrm{~mm}$ potassium phosphate buffer ( $\mathrm{pH} 7.4$ ) with $0(\bigcirc), 50(\triangle), 100(\square), 200$ (O), $300(\Delta)$, or $400(\square) \mathrm{mm}-\mathrm{NaCl}$. The $\mathrm{NaCl}$ was added to the bacteroid suspension $5 \mathrm{~min}$ before addition of radioactive substrate. The points shown are the mean values of duplicate assays from three different experiments; error bars indicate SD. The insert shows the effect of $\mathrm{NaCl}$ concentration (mM) on the initial rate of glycine betaine uptake $\left[\mathrm{nmol} \mathrm{min}^{-1}(\mathrm{mg} \text { protein })^{-1}\right]$. 
activity could be that the periplasmic binding protein might be lost during bacteroid differentiation or isolation. This possibility is currently under study.

To determine whether or not the stimulation of glycine betaine uptake is specific to $\mathrm{NaCl}$, other electrolytes or non-electrolytes were added to the incubation medium at concentrations osmotically equivalent to $200 \mathrm{mM}-\mathrm{NaCl}$ (Table 1). $\mathrm{NaCl}$ and $\mathrm{Na}_{2} \mathrm{HPO}_{4}$ greatly enhanced uptake (120- and 70-fold stimulation respectively), whereas $\mathrm{LiCl}$ and $\mathrm{KCl}$ had much less effect (only 15- and 8-fold stimulation, respectively). Moreover, adding organic compounds (sucrose or mannitol) to the incubation medium led to only a 5-fold increase in uptake. These results differ from those obtained previously in freeliving cells of $R$. meliloti (Pocard, 1987), where the stimulation observed with $\mathrm{NaCl}(300 \mathrm{~mm})$ was only four times that of the control cells. Furthermore, in cultured cells $\mathrm{KCl}(300 \mathrm{mM})$ had the same effect as $\mathrm{NaCl}$, and sucrose $(460 \mathrm{mM})$ gave a stimulation $2 \cdot 7$-fold higher than $\mathrm{NaCl}$. Whether glycine betaine uptake by bacteroids is coupled to $\mathrm{Na}^{+}$is not known, but these experiments show that the stimulation of uptake is not simply a consequence of elevated external osmotic pressure.

\section{Kinetics of glycine betaine transport}

The concentration dependence of glycine betaine uptake was studied by varying the substrate concentration $(0.5-$ $100 \mu \mathrm{M})$ and measuring the velocity of uptake over 30 min by bacteroids incubated in $200 \mathrm{~mm}-\mathrm{NaCl}$ (Fig. 3). Glycine betaine uptake was a saturable process; it showed Michaelis-Menten kinetics, and from the data the apparent $K_{\mathrm{m}}$ was calculated to be about $8.3 \mu \mathrm{M}$ with a value for $V$ of $0.84 \mathrm{nmol} \mathrm{min}^{-1}(\mathrm{mg} \text { protein })^{-1}$. There was

\section{Table 1. Effect of various solutes on [methyl- $\left.{ }^{14} \mathrm{C}\right]$ glycine betaine uptake by bacteroids of $R$. meliloti}

Incubation mixtures contained $50 \mu \mathrm{M}-\left[\right.$ methyl $\left.-{ }^{14} \mathrm{C}\right]$ glycine betaine and bacteroids $(0 \cdot 1 \mathrm{mg}$ protein) in $25 \mathrm{~mm}$-potassium phosphate buffer $(\mathrm{pH} \mathrm{7.4)}$ with added electrolytes or non-electrolytes at concentrations osmotically equivalent to $200 \mathrm{~mm}-\mathrm{NaCl}$. Addition of osmolytes was done as described in Fig. 2. Mean results of duplicates from two separate experiments are shown \pm SD.

\begin{tabular}{lccc}
\hline \hline Osmolyte & $\begin{array}{c}\text { Concn } \\
(\mathrm{mM})\end{array}$ & $\begin{array}{c}\text { Glycine betaine uptake } \\
{\left[\mathrm{nmol}(30 \mathrm{~min})^{-1}(\mathrm{mg} \text { protein })^{-1}\right]}\end{array}$ & $\begin{array}{c}\text { Stimulation* } \\
\text { (-fold) }\end{array}$ \\
\hline None & & $0 \cdot 2 \pm 0 \cdot 01$ & 0 \\
$\mathrm{NaCl}$ & 200 & $23 \cdot 2 \pm 0 \cdot 6$ & 120 \\
$\mathrm{Na}_{2} \mathrm{HPO}_{4}$ & 175 & $13 \cdot 8 \pm 0 \cdot 2$ & 70 \\
$\mathrm{LiCl}$ & 200 & $3 \cdot 1 \pm 0 \cdot 05$ & 15 \\
$\mathrm{KCl}$ & 200 & $1 \cdot 6 \pm 0 \cdot 05$ & 8 \\
Sucrose & 300 & $1 \cdot 1 \pm 0 \cdot 15$ & 5 \\
Mannitol & 350 & $1 \cdot 1 \pm 0 \cdot 05$ & 5 \\
\hline \hline
\end{tabular}

* Compared to the value obtained in the absence of osmolyte.

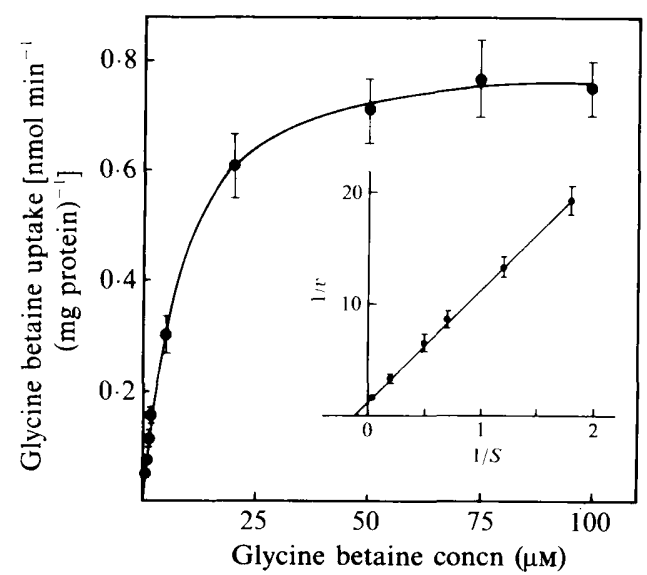

Fig. 3. Kinetics of $\left[\right.$ methyl $\left.{ }^{14} \mathrm{C}\right]$ glycine betaine uptake by bacteroids of $R$. meliloti. Glycine betaine uptake was measured as described in Methods; incubation mixtures contained bacteroids $(0 \cdot 1 \mathrm{mg}$ protein) in 25 mM-potassium phosphate buffer (pH 7.4) with $200 \mathrm{mM} \mathrm{NaCl}$. The points shown are the mean values of three determinations. The insert is a Lineweaver-Burk plot of the reciprocal initial rate of glycine betaine uptake $\left(\mathrm{nmol}^{-1} \cdot \min \cdot \mathrm{mg}\right.$ protein) against the reciprocal of concentration $\left(\mu \mathrm{M}^{-1}\right)$.

no significant difference between cultured cells and bacteroids in apparent $K_{\mathrm{m}}$ but $V$, as previously mentioned, was much lower in bacteroids than in free-living cells. Most of the studies on metabolite uptake by bacteroids have given apparent $K_{\mathrm{m}}$ values in the micromolar range, e.g. $40 \mu \mathrm{M}$ for succinate and malate in bacteroids of $B$. japonicum strain USDA 110 (Reibach \& Streeter, 1984) and 10-15 $\mu \mathrm{M}$ for the same substrates in bacteroids of $B$. japonicum strain USDA 3278 (San Francisco \& Jacobson, 1985).

\section{Effect of energy-yielding substrates and inhibitors on glycine betaine uptake}

We attempted to define the conditions for maximal glycine betaine uptake by incubating the bacteroids with various oxidizable carbon substrates or ATP, in the absence or presence of $200 \mathrm{mM}-\mathrm{NaCl}$. In both conditions, supplying bacteroids with $20 \mathrm{~mm}$-succinate, which greatly enhanced $\mathrm{O}_{2}$ consumption, surprisingly had no effect on glycine betaine uptake. Sucrose, fructose, glucose $(20 \mathrm{mM})$ or ATP $(2 \mathrm{mM})$ did not have any significant effect on uptake, whereas pre-incubation with fumarate and malate led to a small reduction in the accumulation of glycine betaine $(7 \%$ and $12 \%$, respectively; results not shown).

Potassium cyanide $(\mathrm{KCN} ; 0.5 \mathrm{~mm})$, a respiratory inhibitor, greatly reduced $(81 \%)$ glycine betaine uptake by bacteroids in the presence of $200 \mathrm{~mm}-\mathrm{NaCl}$. The protonophore carbonyl cyanide $m$-chlorophenylhydra- 
zone $(\mathrm{CCCP} ; 10 \mu \mathrm{M})$, which inhibits the formation of a $\mathrm{pH}$ gradient by $B$. japonicum bacteroid suspensions (Bhandari \& Nicholas, 1985), strongly inhibited glycine betaine uptake $(96 \%$ inhibition). However, arsenate ( $5 \mathrm{mM}$ ), which can compete with phosphate so that very little functional ATP is formed, was without any inhibitory effect on uptake. These results confirm that glycine betaine accumulation in bacteroids of $R$. melilot $i$ is via an active transport system and suggest that direct utilization of ATP by the glycine betaine transport mechanism is unlikely. However, the results also suggest that at least a portion of the glycine betaine taken up may be coupled to proton movement. We are aware of the difficulties in interpreting these results and determining the driving force. A more detailed analysis of the components of glycine betaine uptake system, in both free-living and bacteroids of $R$. meliloti, is needed. Such studies are in progress in our laboratory.

\section{Specificity of glycine betaine uptake}

The specificity of the glycine betaine transport system was determined by experiments in which various structural analogues at 10 times and 100 times the glycine betaine concentration were allowed to compete with uptake of $\left[\right.$ methyl $\left.-{ }^{14} \mathrm{C}\right]$ glycine betaine. The relative accumulation of $\left[{ }^{14} \mathrm{C}\right]$ glycine betaine was determined by reference to untreated controls (Table 2). As expected, unlabelled glycine betaine was the most effective competitor $(89 \%$ and $98 \%$ inhibition at 0.5 and $5 \mathrm{mM}$, respectively). When used at $0.5 \mathrm{~mm}$, all other betaines were without effect on glycine betaine uptake. Similarly, non-methylated compounds, such as glycine and proline, did not cause any inhibition. Higher concentrations of

Table 2. Effect of unlabelled competitors on [methyl-14C]glycine betaine uptake by bacteroids of $R$. meliloti

Uptake assays were done as described in Methods with $50 \mu \mathrm{M}$ [methyl $-{ }^{14} \mathrm{C}$ ]glycine betaine and bacteroids $(0.1 \mathrm{mg}$ protein) in $25 \mathrm{~mm}$-potassium phosphate buffer (pH 7.4) with $200 \mathrm{~mm}-\mathrm{NaCl}$, and 0.5 or $5 \mathrm{mM}$ competitor. Data are given as a percentage of the non-inhibited uptake rate, which was $25 \cdot 2 \pm 1 \cdot 1 \mathrm{nmol}(30 \mathrm{~min})^{-1}$ (mg protein) $)^{-1}$.

\begin{tabular}{lcc}
\hline & \multicolumn{2}{c}{$\begin{array}{c}\text { Percentage inhibition at an } \\
\text { inhibitor concentration of: }\end{array}$} \\
\cline { 2 - 3 } \multicolumn{1}{c}{ Addition } & $0.5 \mathrm{mM}$ & $5 \mathrm{mM}$ \\
\hline None & 0 & 0 \\
Glycine betaine & $89 \pm 2$ & $98 \pm 1$ \\
Choline & $-6 \pm 10$ & $-25 \pm 6$ \\
Proline betaine & $0 \pm 10$ & $25 \pm 4$ \\
$\gamma$-Butyrobetaine & $-10 \pm 7$ & $-6 \pm 2$ \\
Trigonelline & $2 \pm 6$ & $82 \pm 2$ \\
Glycine & $1 \pm 1$ & $-9 \pm 2$ \\
Proline & $-9 \pm 1$ & $-10 \pm 1$ \\
\hline \hline
\end{tabular}

competitors $(5 \mathrm{~mm})$ were also ineffective except in the case of proline betaine and trigonelline. However, when present in 100-fold excess, proline betaine had only a slight inhibitory effect $(25 \%$ inhibition) on glycine betaine transport. The strong inhibition $(82 \%)$ observed with trigonelline was almost certainly the consequence of the toxicity of this compound at the concentration used, because whereas a concentration of $3 \mathrm{~mm}$-trigonelline allows good growth of $R$. meliloti, $6 \mathrm{~mm}$ kills the cells. Thus, it seems unlikely that proline betaine and trigonelline are transported by the same system as glycine betaine. Therefore, the glycine betaine uptake system in $R$. meliloti bacteroids possesses considerable structural specificity. Work with $E$. coli has also shown a strong specificity for glycine betaine transport system; the purified periplasmic binding protein binds glycine betaine with high affinity but has no affinity for either choline or proline (Barron et al., 1987). While proline betaine was not tested by these authors, we have shown that proline betaine uptake by $R$. meliloti is not likely to be dependent on a periplasmic binding protein (Gloux \& Le Rudulier, 1989).

\section{Uptake of the glycine betaine analogues choline and proline betaine}

Because both proline betaine and choline are transported by free-living cells of $R$. meliloti (Pocard et al., 1989; Gloux \& Le Rudulier, 1989), and since they are not competitors of glycine betaine transport by $R$. meliloti bacteroids, measurements of uptake by bacteroid suspensions were done using $50 \mu \mathrm{M}-\left[\right.$ methyl $\left.{ }^{-14} \mathrm{C}\right]$ choline and $10 \mu \mathrm{M}-\left[{ }^{14} \mathrm{C}\right]$ proline betaine. Uptake of both compounds was nearly constant for about $30 \mathrm{~min}$. At low osmolarity, the rate of proline betaine uptake was similar to that of glycine betaine while the rate of choline uptake was about 9 -fold greater. Addition of $200 \mathrm{~mm}-\mathrm{NaCl}$ caused an approximately 25 - and 2-fold stimulation of proline betaine and choline uptake, respectively (Table 3 ).

\section{Table 3. Uptake of $\left[\right.$ methyl- $\left.{ }^{14} \mathrm{C}\right]$ choline and $\left[{ }^{14} \mathrm{Clproline}\right.$ betaine by bacteroids of $R$. meliloti}

Incubation mixtures contained $50 \mu \mathrm{M}-\left[\right.$ methyl- $\left.{ }^{14} \mathrm{C}\right]$ choline or $10 \mu \mathrm{M}-\left[{ }^{14} \mathrm{C}\right]$ proline betaine and bacteroids $(0 \cdot 1 \mathrm{mg}$ protein) in 25 mM-potassium phosphate buffer (pH 7.4) with 0,200 or $400 \mathrm{~mm}-\mathrm{NaCl}$. Data are means of results from two separate experiments $\pm \mathrm{SEM}$.

\begin{tabular}{|c|c|c|}
\hline \multirow{2}{*}{$\begin{array}{c}\mathrm{NaCl} \\
\text { concn } \\
(\mathrm{mM})\end{array}$} & \multicolumn{2}{|c|}{$\begin{array}{c}\text { Uptake } \\
{\left[\mathrm{nmol}(30 \mathrm{~min})^{-1}(\mathrm{mg} \text { protein })^{-1}\right]}\end{array}$} \\
\hline & Choline & Proline betaine \\
\hline None & $1.5 \pm 0.1$ & $0.16 \pm 0.02$ \\
\hline 200 & $2 \cdot 7 \pm 0 \cdot 2$ & $3.95 \pm 0.15$ \\
\hline 400 & $1.9 \pm 0.1$ & Not determined \\
\hline
\end{tabular}


Under these conditions, after 30 min uptake, the total amount of both compounds that had been taken up was about six to nine times lower than that of glycine betaine. Some of the difference may be due to the fact that choline and proline betaine concentrations in the assay might have been less than optimal.

When choline uptake was studied as a function of substrate concentration over the range 5-150 $\mu \mathrm{M}$, a nonlinear Lineweaver-Burk plot was obtained with bacteroids maintained at low or high osmolarity. This suggests that a high-affinity activity as well as a low-affinity transport system might be present in $R$. meliloti bacteroids, and is consistent with results obtained with free-living cells (Pocard et al., 1989). In $200 \mathrm{~mm}-\mathrm{NaCl}$ (Fig. 4), the approximate $K_{\mathrm{m}}$ values for these activities were 10 and $100 \mu \mathrm{M}$, respectively with values for $V$ of 27 and $125 \mathrm{pmol} \mathrm{min}^{-1}(\mathrm{mg} \text { protein })^{-1}$. Succinate $(20 \mathrm{mM})$ or ATP ( $2 \mathrm{mM}$ ) did not stimulate these activities but the uptake was strongly inhibited by $0.5 \mathrm{~mm}-\mathrm{KCN}$ and $10 \mu \mathrm{M}-\mathrm{CCCP}$. However, a residual uptake activity (about $46 \%$ and $26 \%$, respectively, of the non-inhibited assay) was always observed in the presence of $\mathrm{KCN}$ and CCCP. This suggests that a substantial amount of choline is taken up by passive diffusion, a process which also occurs in the case of malate and succinate uptake by bacteroids of B. japonicum (Reibach \& Streeter, 1984).

It is of interest that isolated bacteroids of $R$. meliloti are able to transport glycine betaine, choline and proline betaine, all of which, are osmoprotective agents in freeliving and symbiotic nitrogen-fixing bacteria (Le Rudulier \& Bouillard, 1983; Pocard et al., 1989). We have previously shown that nitrogenase activity of Klebsiella pneumoniae, which is completely inhibited under conditions of salt stress, is significantly restored in the presence of glycine betaine, proline betaine and other related compounds (Le Rudulier et al., 1984b). Thus, one

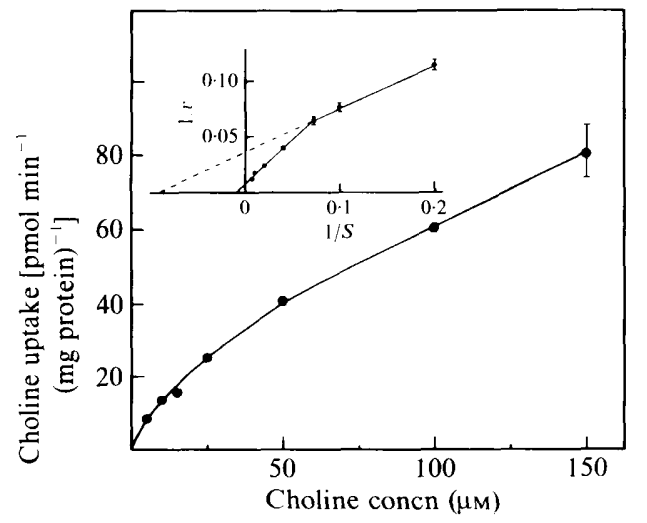

Fig. 4. Kinetics of $\left[\right.$ methyl $\left.-{ }^{14} \mathrm{C}\right]$ choline uptake by bacteroids of $R$. meliloti. Experimental conditions etc. as described in Fig. 3. might expect a beneficial role for these molecules in the maintenance of nitrogenase activity of bacteroids subjected to salt stress. Further experiments are required to clarify this point.

This research was supported by the Centre National de la Recherche Scientifique. The authors wish to thank Paul Hervochon and Marie Christine Poggi for their excellent technical assistance, and Professors J. G. Streeter and J. Rigaud for their helpful discussions.

\section{References}

Barron, A., Jun, J. U. \& Villarejo, M. (1987). Purification and characterization of a glycine betaine binding protein from Escherichia coli. Journal of Biological Chemistry 262, 11841-11846.

Bhandari, B. \& Nicholas, D. J. D. (1985). Proton motive force in washed cells of Rhizobium japonicum and bacteroids from Glycine max. Journal of Bacteriology 164, 1383-1385.

BeKki, A., Trinchant, J. C. \& Rigaud, J. (1987). Nitrogen fixation $\left(\mathrm{C}_{2} \mathrm{H}_{2}\right.$ reduction) by Medicago nodules and bacteroids under sodium chloride stress. Physiologia Plantarum 71, 61-67.

BERgERSEN, F. J. \& TURNER, G. L. (1970). Gel filtration of nitrogenase from soybean root nodule bacteroids. Biochimica et Biophysica Acta 214, 28-36.

Bernard, T., Pocard, J. A., Perroud, B. \& Le Rudulier, D. (1986). Variations in the response of salt-stressed Rhizobium strains to betaines. Archives of Microbiology 143, 359-364.

CORTI, U. A. (1949). Über Ergebnisse der Methylierung von Tyrosine mit Dimethylsulfate and einige Derivate des $N$-Methyltyramin. Helvetica Chimica Acta 32, 681-686.

Giddings, T. H. \& Hanson, A. D. (1982). Water stress provokes a generalized increase in phosphatidylcholine turnover in barley leaves. Planta 155, 493-501.

Gloux, K. \& LE RUdulier, D. (1989). Transport and catabolism of proline betaine in salt-stressed Rhizobium meliloti. Archives of Microbiology 151, 143-148.

Hitz, W. D., Rhodes, D. \& Hanson, A. D. (1981). Radiotracer evidence implicating phosphoryl and phosphatidyl bases as intermediates in betaine synthesis by water-stressed barley leaves. Plant Physiology 68, 814-822.

IKUTANI, Y. (1968). Studies of the $N$-oxides of $N, N$-dialkylamino acids. I. The synthesis of $N, N$-dimethyl neutral amino acids and corresponding $N$-oxides. Bulletin of the Chemical Society of Japan 41, 1679 1691.

Le Rudulier, D. \& Bouillard, L. (1983). Glycine betaine, an osmotic effector in Klebsiella pneumoniae and other members of the Enterobacteriaceae. Applied and Environmental Microbiology 46, 152 159.

Le Rudulier, D., Strøm, A. R., Dandekar, A. M., Smith, L. T. \& VALENTINE, R. C. (1984a). Molecular biology of osmoregulation. Science 224, 1064-1068.

Le Rudulier, D., Bernard, T., Goas, G. \& Hamelin, J. (1984b). Osmoregulation in Klebsiella pneumoniae: enhancement of anaerobic growth and nitrogen fixation under stress by proline betaine, $\gamma$ butyrobetaine, and other related compounds. Canadian Journal of Microbiology 30, 299-305.

O'Gara, F. \& Shanmugan, K. T. (1976). Regulation of nitrogen fixation by Rhizobia: export of fixed $\mathbf{N}_{2}$ as $\mathbf{N H}_{4}^{+}$. Biochimica et Biophysica Acta 437, 313-321.

Perroud, B. \& Le Rudulier, D. (1985). Glycine betaine transport in Eschericia coli: osmotic modulation. Journal of Bacteriology 161, 393 401.

POCARD, J. A. (1987). La glycine bétä̈ne: effect osmoprotecteur, transport et métabolisme chez Rhizobium meliloti en culture in vitro et en symbiose avec Medicago sativa $L$. Doctoral thesis, University of Rennes I, France. 
Pocard, J. A., Bernard, T., Goas, G. \& Le Rudulier, D. (1984) Restauration partielle, par la glycine bétaïne et la proline bétaïne, de l'activité fixatrice d'azote de jeunes plantes de Medicago sativa L. soumises à un stress hydrique. Comptes Rendus de l'Académie des Sciences 298, 477-480.

Pocard, J. A., Bernard, T., Smith, L. T. \& Le Rudulier, D. (1989). Characterization of three choline transport activities in Rhizobium meliloti: modulation by choline and osmotic stress. Journal of Bacteriology 171, 531-537.

ReibaCH, P. H. \& Streeter, J. G. (1984). Evaluation of active versus passive uptake of metabolites by Rhizobium japonicum bacteroids. Journal of Bacteriology 159, 47-52.

Rigaud, J., Bergersen, F. J., Turner, G. L. \& Daniel, R. M. (1973). Nitrate-dependent anaerobic acetylene-reduction and nitrogenfixation by soybean bacteroids. Journal of General Microbiology 77, 137-144.

Salminen, S. O. \& Streeter, J. G. (1987). Uptake and metabolism of carbohydrates by Bradyrhizobium japonicum bacteroids. Plant Physiology 83, 535-540.
San Francisco, M. J. D. \& Jacobson, G. R. (1985). Uptake of succinate and malate in cultured cells and bacteroids of two slowgrowing species of Rhizobium. Journal of General Microbiology 131, $765-773$.

SeTHI, J. K. \& Carew, D. P. (1974). Growth and betaine formation in Medicago sativa tissue culture. Phytochemistry 13, 321-324.

Sirois, J. C. \& Peterson, E. A. (1982). A rapid screening method for Rhizobium meliloti symbiotic nitrogenase activity. Canadian Journal of Microbiology 28, 265-268.

Smith, L. T., Pocard, J. A., Bernard, T. \& Le Rudulier, D. (1988). Osmotic control of glycine betaine biosynthesis and degradation in Rhizobium meliloti. Journal of Bacteriology 170, 3142-3149.

Stock, J. B., Rauch, B. \& Roseman, S. (1977). Periplasmic space in Salmonella typhimurium and Escherichia coli. Journal of Biological Chemistry 252, 7850-7861.

Waters, J. K., KarR, D. B. \& Emerich, D. W. (1985). Malate dehydrogenase from Rhizobium japonicum 3 I lb-143 bacteroids and Glycine max root-nodule mitochondria. Biochemistry 24, 6479-6486. 